\section{AL-AZHAR Dental Journal}

$\mathrm{F} \quad \mathrm{O} \quad \mathrm{r}$
The Official Publication of The Faculty of Dental Medicine For Girls, Al-Azhar University Cairo, Egypt.

Print ISSN 2537-0308 • Online ISSN 2537-0316

ADJ-for Girls, Vol. 6, No. 4, October (2019) - PP. 461:465

\title{
Evaluation of Nonsurgical Management of Chronic Periodontitis Patients With Chronic Kidney Diseases Using Prohepcidin
}

\author{
Ayat F. Mahrous ${ }^{1 *}$, Mai S. Attia ${ }^{2}$, Amany M. Abdallah ${ }^{3}$, Eatemad Shoreibah ${ }^{4}$
}

Codex : 56/1910

azhardentj@azhar.edu.eg

http://adjg.journals.ekb.eg

DOI: $10.21608 /$ adjg.2019.7723.1096

\begin{abstract}
Purpose: This study was aimed to define the effect of nonsurgical periodontal therapy on chronic periodontitis in chronic kidney disease patients and healthy patients by detection of prohepcidin level in the blood. Materials and methods: The study included 20 chronic periodontitis patients that were divided into:-Group I included 10 patients with chronic kidney disease; Group II which involved 10 healthy patients. Chronic periodontitis was defined through probing pocket depth and by clinical attachment level. All clinical and biochemical parameters were evaluated afterward 3 months of non-surgical periodontal cure. Results: The improvement in clinical parameters showed the efficacy of NSPT in both groups. The periodontal therapy was the cause to reduce prohepcidin level in both groups and a higher reduction in CKD group in comparison to control group at baseline and after 3 months. Conclusion: By reduction in serum prohepcidin and systemic inflammatory response, nonsurgical periodontal treatment has proved to be an effective method to control inflammation seen in patients with CKD.
\end{abstract}

Paper extracted from master thesis titled "Evaluation of non surgical management of chronic periodontitis patients with chronic kidney diseases using prohepcidin".

\section{INTRODUCTION}

Periodontitis is a prolonged inflammatory disease associated with dysbiotic plaque biofilms and characterized by advanced damage of the tooth-supporting apparatus. ${ }^{(1)}$.

\section{Chronic periodontitis,}

nonsurgical management,

chronic kidney disease,

prohepcidin
1. *Dentist at Galaa Teaching Hospital.Email: dr.ayat_fouad@hotmail.com
2. Assistant professor of oral Medicine, Periodontology, Diagnosis and Radiology Department, Faculty of Dental Medicine for Girls, Al -Azhar University.Mai_shafik@yahoo.com

3. Assistant professor of Internal Medicine, Faculty of Medicine for Girls, Al- Azhar University.Dr_amanyabdallah@yahoo.com

4. Professor of Oral Medicine, Periodontology, Diagnosis and Radiology Department, Faculty of Dental Medicine for Girls, AlAzhar University.eshoreibah@yahoo.com 
The oral cavity contains millions of bacteria that can cause periodontitis and caries. For several years, the relationship between periodontal bacteria and systemic diseases has been discovered. Periodontal disease has been related to systemic disease; as well, systemic disease can have an influence on oral health. This is a bidirectional connection and the bond is inflammation ${ }^{(2)}$.

Periodontal pathogens can adhere, enter, and thrive in coronary endothelial cells leading to formation of atheroma. Stimulatingly, it can be expected that periodontal disease applies the same effects inside the vasculature of the kidney as cardiovascular diseases and CKD have similar risk factors ${ }^{(3)}$.

Chronic renal disease is a worldwide disease that defined as renal damage for more than 3 months manifested by structural and/or functional defects of the kidney with reduction of the glomerular filtration rate (GFR) demonstrated by markers of kidney damage in the composition of urine and blood with tests that have consequences on health ${ }^{(4)}$. With GFR level is smaller than $60 \mathrm{ml} / \mathrm{min} / 1.73 \mathrm{~m}^{2}$ for 3 months ${ }^{(5)}$.

A relationship between high levels of C-reactive protein (CRP) and interleukin-6 (IL-6) and periodontitis has been shown by some studies ${ }^{(6,7)}$. Accordingly, periodontitis has recently been included as a nontraditional risk factor for CKD ${ }^{(8)}$. In addition to the known inflammatory markers, hepcidin is considered to be effective in the assessment of inflammatory conditions ${ }^{(9)}$.

Hepcidin is a peptid hormone that was discovered simultaneously as an antibacterial protein found in human urine. This antimicrobial protein is produced by the liver, which is recently considered as a factor which regulate the dietary iron up take and utilization from hepatic stores and macrophages ${ }^{(10)}$. Hepcidin synthesis is induced by IL-6 ${ }^{(9)}$, Also it may related to host defense indirectly by decreasing iron concentrations, which is essential for microbial growth ${ }^{(11,12)}$.
Guidelines of the American Dental Association (ADA) showed that mechanical periodontal therapy is still the standard for nonsurgical therapy and should be used as the first choice for treatment the periodontitis ${ }^{(13,14)}$.

\section{MATEIAL AND METHODS}

This study was done during period from January till August 2018. A total of 20 patients with age from (32-54 years), all of them had moderate to severe chronic periodontitis, and received NSPT. Patients were distributed into two groups:

Group I; consisted of CKD(stage 5) patients under hemodialysis and were recruited from Al-Azhar University Hospitals units(Al-Zahraa),

Group II; ( control group) those were healthy voluntary and attended to the Out-patient Clinics of faculty of dentistry, Al-Azhar University.

All Patients were selected according criteria of having periodontitis with probing depth $\geq 5 \mathrm{~mm}$ and attachement level $\geq 4 \mathrm{~mm}$ and did not receive periodontal treatment, antibiotics or anti-inflammatory therapy in the past six months before the examination which would affect the immune system , Smokers and pregnant women were excluded.

Evaluation of periodontal status of each patient was measured by: Plaque Index (Pl), Gingival Index (GI), Probing Depth(PD), Clinic Attachment Level (CAL). All parameters have been taken at baseline and at three months intervals by using Williams graduated. Readings were obtained from six specific sites on each tooth: distofacial, midfacial, mesiofacial, distolingual, midlingual, and mesiolingual, The deepest PPD was selected for each tooth per patient.

All patients in both groups were treated with phase I periodontal therapy that had been completed by using ultrasonic device, Local anesthesia was given to the patient when needed and root debridement of all deep pockets was performed by 
using universal curettes on the same visit. Oral hygiene instructions included brushing teeth with soft dental brush and using interdental aids once a day were prescribed for each patient. Follow up visits at 30,45,60 days , instructions for supra-gingival prophylaxis at each visit were provided to ensure proper oral hygiene.

Blood samples have been collected for analysis of prohepcidin at baseline and 3 months after. Samples were collected in tubes contained anticoagulant EDTA after 12 hours of fasting between 7:00 and 9:00 am. The analysis of prohepcidin was done by the enzyme-linked immunosorbent assay (ELISA) technique of human Pro-Hepcidin kit.

\section{RESULTS}

\section{Clinical evaluation:}

Group I (CKD) showed higher mean value of Gingival Index (GI) at baseline and after 3 months with no significant difference between both groups, The absolute difference after treatment revealed a similar decrease (-51.67) in both groups, with no significant difference.

Plaque Index (PI) recorded a higher mean value in group I (CKD) without significant difference between both groups . Regarding, a greater percent decrease was recorded in group II $(-0.90 \pm 0.74)$, in comparison to group I (CKD) $(-0.50 \pm 0.53)$, with no significant difference $(\mathrm{p}=0.21)$.(table 1$)$.

A greater percent decrease in Probing Depth (PD) was recorded in group II $(-1.70 \pm 0.82)$, in comparison to group I (CKD) $(-1.30 \pm 0.48)$, with no significant difference, while a higher mean value was recorded in group I (CKD) after 3 months and was recorded in group II (control) at baseline.

Mann Whitney U test showed greater percent decrease in Clinical Attachement Level (CAL) in control group (II), in comparison to CKD group (I), with no significant difference $(\mathrm{p}=0.24)$ as shown in table (1).

\section{Biochemical evaluation result:}

At baseline \&after 3 months a higher mean value of pro-hepcidin was recorded in group I (CKD) with a significant difference between both groups, Regarding the absolute difference after treatment, a greater decrease $(-23.99 \pm 14.99)$ was recorded in group I (CKD), compared to group II (control) $(-16.54 \pm 10.17)$, with no significant difference $(\mathrm{p}=0.21)$. The Pearson correlation, after periodontal treatment revealed a weak positive correlation between Pro-hepcidine and probing depth and gingival index with no significant difference.

Table (1): Descriptive statistics of parameters and significance of inter-group difference of percent change between groups (Mann Whitney U test)

\begin{tabular}{|l|c|c|c|}
\hline & $\begin{array}{c}\text { Group I } \\
(\mathbf{C K D}) \\
\text { mean } \pm \text { SD }\end{array}$ & $\begin{array}{c}\text { Group II } \\
(\text { Control) } \\
\text { mean } \pm \text { SD }\end{array}$ & P value \\
\hline PI & $-0.50 \pm 0.53$ & $-0.90 \pm 0.74$ & $0.21 \mathrm{NS}$ \\
\hline GI & $-1.1 \pm 0.74$ & $-0.10 \pm 0.82$ & $0.78 \mathrm{NS}$ \\
\hline PPD & $-1.30 \pm 0.48$ & $-1.70 \pm 0.82$ & $0.13 \mathrm{NS}$ \\
\hline CAL & $-1.40 \pm 0.52$ & $-1.70 \pm 0.82$ & $0.24 \mathrm{NS}$ \\
\hline Prohepcidin & $-12.96 \pm 7.89$ & $-2.04 \pm 1.39$ & $0.00^{*}$ \\
\hline
\end{tabular}

Significance level $p<0.05, \quad N S=$ non-significant, *significant

\section{DISCUSSION}

Periodontitis and chronic renal disease share common risk factors ${ }^{(15)}$ Moreover, both diseases are considered to be risk factors for CVD which can lead to mortality. ${ }^{(16)}$

Regarding, prohepcidin,is a peptide originally discovered as antimicrobial peptides in human blood $^{(17)}$ and urine ${ }^{(18)}$. Production of hepcidin is increased in relation to inflammation ${ }^{(19)}$. A major inflammatory cytokine (IL)-6 facilitate increase of hepcidin level. ${ }^{(20,21)}$. 
Accordingly, the aim of this study was carried through clinical evaluation and biochemical assessment of pro-hepcidin at baseline and after 3 months of nonsurgical periodontal therapy.

The result of the present study showed that all clinical parameters including PI, GI, PPD , CAL in both groups have been decreased by time to reach the least mean value. The outcome of the present study were in agreement with several studies which show decrease/improvement in clinical parameters. $(22,23,24,25)$.This could be explained by improvement in oral hygiene measures followed by patients after instructions and subsequent plaque control visits

At the current study, after non-surgical periodontal therapy in both groups, pro-hepcidin decreased by time to reach lower mean value after 3 months. Higher mean value of pro-hepcidin was recorded in CKD group at baseline, and after 3 months. CKD group showed greater decrease in comparison to Control group between baseline and 3 months. Our result was in agreement with previous study showed elevated level of pro-hepcidin in CKD in presence of inflammation ${ }^{(22)}$.

The improvement that had been shown in the current study reflected the influence of non-surgical therapy in reducing/eliminating the source of inflammation in both groups which is the main stimulus of pro-hepcidine. Studies showed inflammatory mediators decrease as in (IL 6) after periodontal

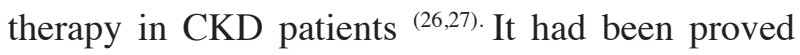
that inflammation resulted in increase of (interleukin 6) and play a crucial role in immune response .It is also considered as a significant stimulus for hepcidin synthesis.Thus, this could explain the decrease in pro-hecidin in relation to the decrease in IL6 following NSPT. ${ }^{(24,27)}$

Finally, chronic periodontitis patients with CKD showed increase in clinical parameters of disease than chronic periodontitis systemically free patients. NSPT resulted in improvement of periodontal conditions with reduction in pro-hepicidin level in both groups.

\section{CONCLUSION}

The supposition that periodontitis induce immune response with forces of inflammatory markers was confirmed. The use of nonsurgical periodontal therapy caused decrease of serum prohepcidin level in patients with CKD.

\section{REFERENCES}

1. Papapanou PN, Sanz M, Buduneli N, Dietrich T, Feres M, Fine DH, et al. Periodontitis: Consensus report of workgroup 2 of the 2017 World Workshop on the Classification of Periodontal and Peri-Implant Diseases and Conditions. J periodontal. 2018; 89:173-82.

2. Bansal M, Rastogi S, Vineeth NS. Influence of periodontal disease on systemic disease: inversion of a paradigm: a review. J Med Life. 2013; 6: 126.

3. Martinez BA, Corcuera MM, Noronha S, Mota P, Ilundain BC, Trapero CJ. Host defence mechanisms against bacterial aggression in periodontal disease: Basic mechanisms. Med Oral Patol Oral Cir Bucal. 2009; 14: 680-5.

4. Levey AS, Coresh J. Chronic Kidney Disease.The lancet. $2012 ; 379: 165-80$

5. Levey AS, Coresh J, Bolton K, Culleton B, Harvey KS, Ikizler TA, et al. K/DOQI Clinical Practice Guidelines for Chronic Kidney Disease: Evaluation, Classification and Satisfaction. Am J Kidney Dis, 2002;39:1-26.

6. Craig RG, Kotanko P, Kamer AR, Levin NW. Periodontal diseases: a modifiable source of systemic inflammation for the end-stage renal disease patient on haemodialysis therapy? Nephrol Dial Transplant. 2006;22:312-5.

7. Marcaccini AM, Meschiari CA, Sorgi CA, Saraiva MCP, Souza AM, Faccioli LH, et al. Circulation interleukin-6 and high-sensitivity $\mathrm{C}$-reactive protein decrease after periodontal therapy in otherwise healthy subjects. J Periodontology. 2009; 80:594-602.

8. Fisher MA, Taylor GW.A prediction model for chronic kidney disease includes periodontal disease. J Periodontology. 2009;80:16-23.

9. Malyszko J, Malyszko JS, Kozminski P, Koc-Zorawska E, Mysliwiec M, Macdougall I. Possible relationship between neutrophil gelatinase-associated lipocalin, hepcidin, and inflammation in haemodialysed patients. Nephron Clin Pract. 2010; 115:268-75. 
10. Taketani S. Aquisition, mobilization and utilization of cellular iron and heme: Endless findings and growing evidence of tight regulation. Tohoku J Exp Med. 2005;205:297-318.

11. De Domenico I, Zhang TY, Koening CL, Branch RW, London N, Lo E, et al. Hepcidin mediates transcriptional changes that modulate acute cytokine-induced inflammatory responses in mice. J Clin invest. 2010; 120:2395-405.

12. Kim A, Nemeth E. New insights into iron regulation and erythropoiesis. Current opinion in hematology. 2015;3:199.

13. Akpinar A, Toker H, Ozdemir H, Bostanci V, Aydin H. The effects of non-surgical periodontal therapy on oxidant and anti-oxidant status in smokers with chronic periodontitis. Arch Oral Biol. 2013; 58:717-23.

14. Matouga AA, El-Shinnawi UM, Hesham AS, El-Farahaty RM. Assessment of 25-Hydroxy Vitamin D3 and Osteocalcin in Chronic Periodontitis Patient. Mansoura J Dent. 2014;1:34-41.

15. Fisher MA, Taylor GW, Shelton BJ, Jamerson KA, Rahman M, Ojo AO, et al. Periodontal disease and other nontraditional risk factors for CKD. American Journal of Kidney Diseases: Am J Kidney Dis, 2008; 51: 45-52.

16. Hansen GM, Egeberg A, Holmstrup P, Hansen PR. Relation of periodontitis to risk of cardiovascular and allcause mortality. Am J Cardiol., 2016; 118:489-93.

17. Krause A, Neitz S, Mägert HJ, Schulz A, Forssmann WG, Schulz-Knappe P, et al. LEAP-1, a novel highly disulfidebonded human peptide, exhibits antimicrobial activity. FEBS Lett. 2000; 480:147-50.

18. Park CH, Valore EV, Waring AJ, Ganz T. Hepcidin, a urinary antimicrobial peptide synthesized in the liver. J Biol Chem. 2001; 276:7806-10.
19. Ganz T. Molecular control of iron transport. J Am Soc Nephrol. 2007; 18:394-400.

20. Nemeth E, Ganz T. Regulation of iron metabolism by hepcidin. Annu Rev Nutr 2006; 26: 323-42.

21. Nemeth E, Rivera S, Gabayan V, Keller C, Taudorf S, Pedersen BK, et al. IL-6 mediates hypoferremia of inflammation by inducing the synthesis of the iron regulatory hormone hepcidin. J Clin Invest 2004; 113: 1271-6.

22. Vilela EM, Bastos JA, Fernandes N, Ferreira AP, Chaoubah A, Bastos MG. Treatment of chronic periodontitis decreases serum prohepcidin levels in patients with chronic kidney disease. Clinics (Sao Paulo, Brazil), 2011; 66: 657-62.

23. Artese HPC, de Sousa CO, Luiz RR, Sansone C, Torres B. Effect of non-surgical periodontal treatment on chronic kidney disease patients. Braz. oral res, 2010; 24: 449-54.

24. Fang F, Wu B, Qu Q, Gao J, Yan W, Huang X, et al. The clinical response and systemic effects of nonsurgical periodontal therapy in end-stage renal disease patients: a 6-month randomized controlled clinical trial. J Clin Periodontol, 2015; 42: 537-46.

25. Almeida S, Figueredo CM, Lemos C, Bregman R, Fischer RG. Periodontal treatment in patients with chronic kidney disease: a pilot study. J Periodontol Res, 2017; 52: 262-7.

26. Nemeth E, Rivera S, Gabayan V, Keller C, Taudorf S, Pedersen BK, et al. IL-6 mediates hypoferremia of inflammation by inducing the synthesis of the iron regulatory hormone hepcidin. J Clin Invest 2004; 113: 1271-6.

27. Guo N, Lin G. Effects of nonsurgical periodontal therapy on serum inflammatory factor levels in patients with chronic kidney disease and periodontitis. Biomed ResIndia, 2017; 28:3899-902. 